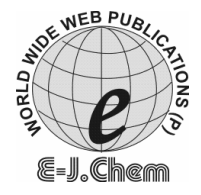

http://www.e-journals.net
ISSN: 0973-4945; CODEN ECJHAO

E-Journal of Chemistry 2009, 6(3), 905-908

\title{
Water Quality Assessment of Groundwater Resources in Nagpur Region (India) Based on WQI
}

\author{
P. N. RAJANKAR ${ }^{{ }^{*}}$, S. R. GULHANE ${ }^{\#}$, D. H. TAMBEKAR ${ }^{\#}$, \\ D. S. RAMTEKE ${ }^{\S}$ and S. R. WATE ${ }^{\S}$
}

\author{
${ }^{\S}$ Environmental Impact \& Risk Assessment Division, Neeri, Nagpur-20, India. \\ \#P.G. Department of Microbiology. SGB Amravati University, Amravati-02, India. \\ prashant_nr@rediffmail.com
}

Received 20 January 2009; Accepted 25 March 2009

\begin{abstract}
Water quality index (WQI) has been calculated for different groundwater sources i.e. dug wells, bore wells and tube wells at Khaperkheda region, Maharashtra (India). Twenty two different sites were selected in post monsoon, winter and summer season. And water quality index was calculated using water quality index calculator given by National Sanitation Foundation (NSF) information system. The calculated WQI showed fair water quality rating in post monsoon season which then changed to medium in summer and winter seasons for dug wells, but the bore wells and hand pumps showed medium water quality rating in all seasons where the quality was slightly differs in summer and winter season than post monsoon season, so the reasons to import water quality change and measures to be taken up in terms of groundwater quality management are required.
\end{abstract}

Keywords: Water quality index, Groundwater quality, National sanitation foundation

\section{Introduction}

Water is one of the most indispensable resources and is the elixir of life. Water constitutes about $70 \%$ of the body weight of almost all living organisms. Life is not possible on this planet without water. It exists in three states namely solid, liquid and gas. It acts as a media for both chemical and biochemical reactions and also as an internal and external medium for several organisms. About $97.2 \%$ of water on earth is salty and only $2.8 \%$ is present as fresh water from which about $20 \%$ constitutes groundwater. Groundwater is highly valued because of certain properties not possessed by surface water ${ }^{1}$. 
The rapid growth of urban areas has further affected the groundwater quality due to over exploitation of resources and improper waste disposal practices. Water is vital to man's existence. Early human civilizations centered on spring and streams. Many civilizations that flourished after developing reliable water supply collapsed when the supply was exhausted or its quality deteriorated ${ }^{2}$.

Water, a natural resource which has been used for different purposes, namely for drinking, domestic, irrigation and industrial, mainly depends on its intrinsic quality hence it is of prime importance to have prior information on quality and quality of water resources available in the region, while planning developmental projects. Peoples around the world have used groundwater as a source of drinking water, and even today more than half the world's population depends on groundwater for survival ${ }^{3}$. The value of groundwater lies not only in its wide spread occurrence and availability but also in its consistent good quality, which makes it an ideal supply of drinking water ${ }^{4}$. Assessment of water quality is very important for knowing the suitability for various purposes ${ }^{5}$. Water Quality Index (WQI) is regarded as one of the most effective way to communicate water quality ${ }^{6-9}$

The WQI, which was developed in the nearly 1970s, can be used to monitor water quality changes in a particular water supply over time, or it can be used to compare a water supply's quality with other water supplies in the region or from around the world. The results can also be used to determine if a particular stretch of water is considered as "healthy."

\section{Experimental}

Groundwater samples collected from dug wells bore wells and tube wells from the Khaperkheda region of Maharashtra, India during the year 2005-06 covering post monsoons, winter and summer periods were analyzed for the present study. Samples were collected in sterilized glass bottles for bacteriology and for physicochemical analysis of sample; the pre cleaned plastic polyethylene bottles were used. Prior to sampling, all the sampling containers were washed and rinsed thoroughly with the groundwater to be taken for analysis.

The samples were analyzed for different physical, chemical and bacteriological parameters including nine parameters of water quality index (BOD, DO, Faecal coliforms, Nitrate, pH, Temperature change, TDS, Total phosphate and Turbidity ${ }^{10}$ using standard methods ${ }^{11}$. DO, $\mathrm{pH}$, and Temperature were measured in the field itself, dissolved nutrients were estimated by spectrophotometrically ("Spectronic", Genesys-2) after filtration of sample, Chloride, hardness, was determined by titration method while barium chloride method was employed for the determination of sulphate.

In bacteriological examination, total coliforms $\left(28{ }^{\circ} \mathrm{C}\right.$ for $\left.24 \mathrm{~h}\right)$ and faecal coliforms $\left(44.5^{\circ} \mathrm{C}\right.$ for $24 \mathrm{~h}$ ) were determined by Membrane Filtration (MF) technique, and the average values were recorded. The TC was enumerated by M-Endo Agar, (Hi-Media Mumbai) which appeared as metallic sheen colour colonies, and FC was enumerated by M-FC Agar, (Hi-Media Mumbai) which appeared as blue colour colonies.

\section{Results and Discussion}

The WQI was calculated using standard $Q$-value of each parameter and weighting factor by using NSF information software and compared with standard water quality rating, Table 1. The minimum, maximum and average of total 22 values of WQI rating for the post monsoon, summer and winter season are presented in Table 2. The graphical representation of WQI rating in different season is given in Figure 1. 
Table 1. Water Quality Index scale recommended by NSF.

\begin{tabular}{ccccc}
\hline Source & & Post monsoon & Summer & Winter \\
\hline & Min & 46 & 47 & 55 \\
Dug well & Max & 65 & 66 & 69 \\
& Average & 52.5 & 55.37 & 61 \\
\hline & Min & 59 & 59 & 61 \\
Bore well & Max & 63 & 62 & 64 \\
& Average & 61 & 60.5 & 62.5 \\
\hline \multirow{5}{*}{ Hand Pump } & Min & 46 & 53 & 59 \\
& Max & 55 & 60 & 70 \\
\cline { 1 - 3 } & Average & 49 & 57.5 & 66.25 \\
\hline
\end{tabular}

Table 2. Average WQI rating of groundwater sources in different season.

\begin{tabular}{cc}
\hline WQI Rating & Quality of Water \\
\hline $91-100$ & Excellent water quality \\
$71-90$ & Good water quality \\
$51-70$ & Medium or average water quality \\
$26-50$ & Fair water quality \\
$0-25$ & Poor water quality \\
\hline
\end{tabular}

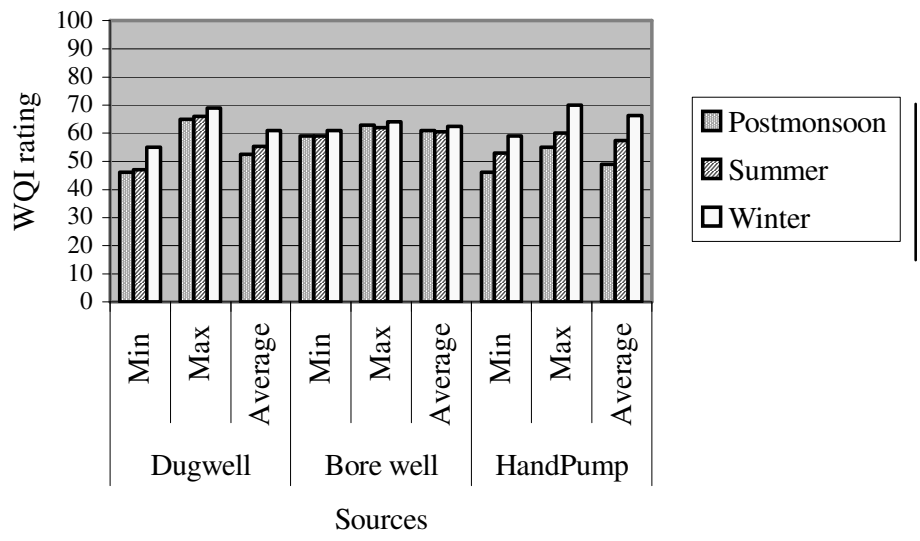

Figure 1. Representation of WQI rating in all season.

The observed range of WQI in post monsoon was 52.5, 61 and 49 in dug wells, bore wells and hand pump respectively. In summer it was 55.4, 60.5 and 57.5 in dug wells, bore wells and hand pump respectively and in winter it was found 61, 62.5 and 66.25 in dug wells, bore wells and hand pump respectively. The water at almost all the sites showed the increasing trend of the WQI index in post monsoon, summer and winter Table 1.

\section{Conclusion}

On the basis of the above discussion, it may be concluded that the underground drinking water at almost all the sites at Khaperkheda was highly polluted as indicated by WQI. In few sites, it was moderately polluted in the catchments study area. The drinking water is polluted with reference to almost all the water quality physicochemical parameters studied. 
The quality of IM2 water was found better than the water of ordinary hand pumps. Therefore, the use of ordinary hand pumps should be discouraged. The drinking water quality was found to start deteriorating, after the onset of monsoon. People dependent on this water are often prone to health hazards due to polluted drinking water. Therefore, some effective measures are urgently required to enhance the drinking water quality by delineating an effective water quality management plan for the Khaperkheda, Nagpur India.

\section{Acknowledgements}

The authors hereby acknowledge the kind and wholehearted support of the Director, NEERI, Nagpur, M S. India. We also take this opportunity to thank Dr. Atul Kulkarni, Data Sol Consultancy, Nagpur, M.S. India, for his overall support in data management and analysis.

\section{References}

1. Goel P K, Water Pollution - Causes, Effects and Control, New Age Int. (P) Ltd., New Delhi, 2000.

2. Mohrir A, Ramteke D S, Moghe C A, Wate S R and Sarin R, Surface and groundwater quality assessment in Bina region, IJEP, 2002, 22(9), 961-969.

3. UNESCO, Groundwater UNESCO Environmental and development briefs no. 2, 1992, 14P.

4. Groundwater pollution, International Hydrological Programme, UNESCO, 2000.

5. Ramkrishnaiah S and Sri Y Babu Rao, Environmental and water quality studies in AP state - A case study, 1991.

6. Procceding of the international conference on water and environmental (WE-2003). Bhopal India, Allied publishers Pvt. Ltd., Dec 15-18, 2003.

7. Kannan K, Fundamentals of Environmental Pollution, S. Chand \& Company Ltd., New Delhi, 1991.

8. Sinha D K and Shrivastava A K, Water quality index for river Sai at Rae Bareli for the pre monsoon period and after the onset of monsoon, Indian J Env Prot., 1994, 14(5), 340-345.

9. Pradhan S K Patnaik D and Rout S P, 2001, Groundwater quality index for groundwater around a phosphatic fertilizers plant, Indian J Environ Protect., 21(4), 355-358.

10. Consumer Information-Water Quality Index/ 100306/NSF -www.google.com

11. APHA, Standard Methods for the Examination of Water and Wastewater. $17^{\text {th }}$ Ed. American Public Health Association, Washington, DC, 1989. 


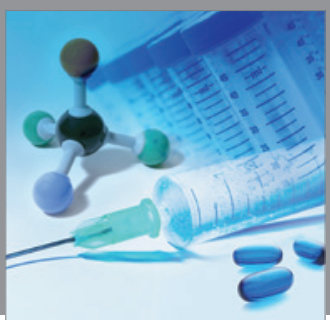

International Journal of

Medicinal Chemistry

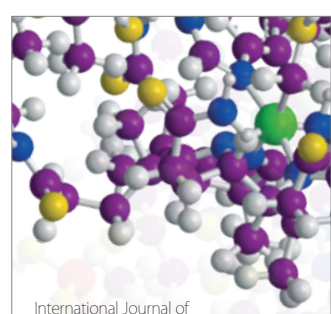

Carbohydrate Chemistry

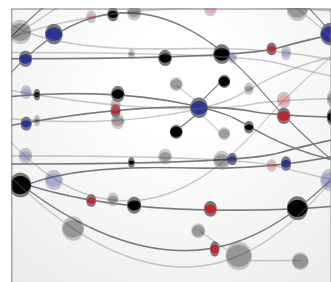

The Scientific World Journal
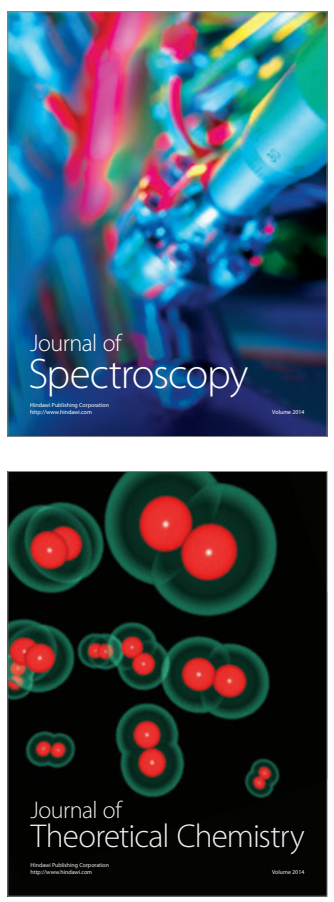
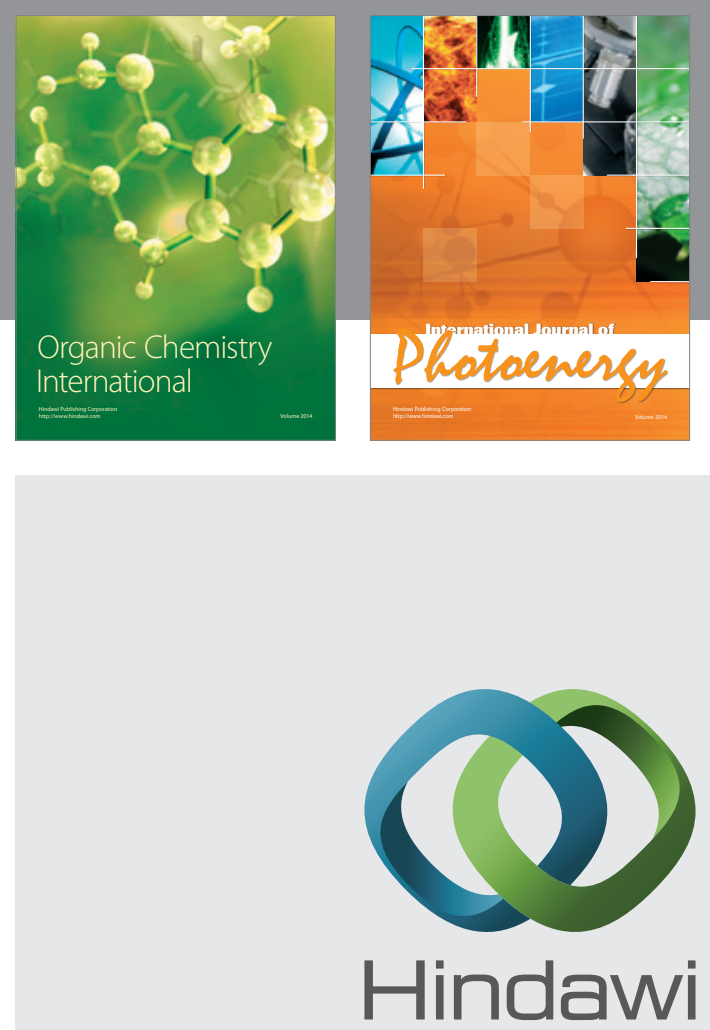

Submit your manuscripts at

http://www.hindawi.com
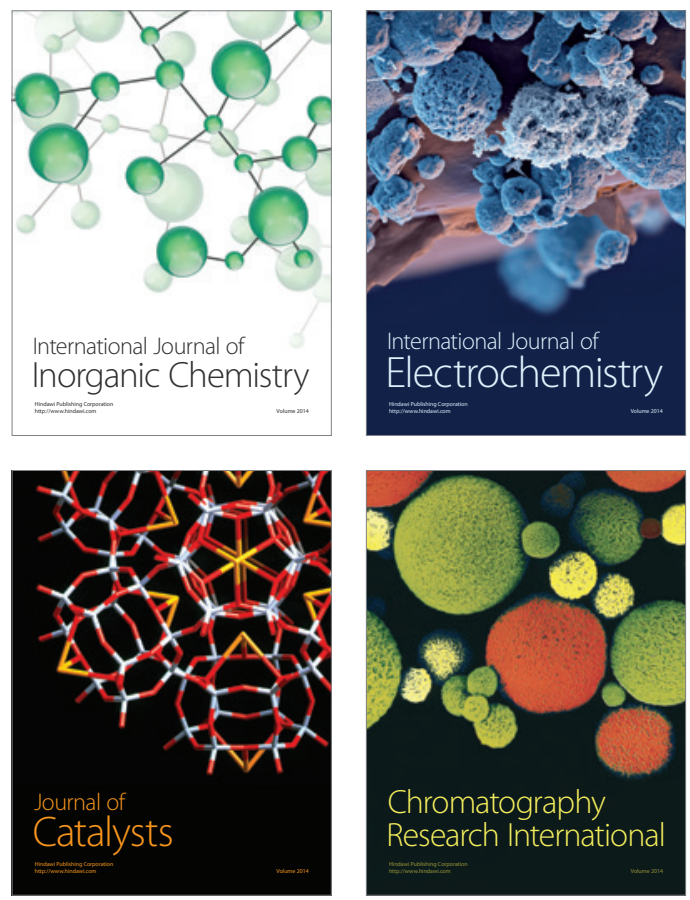
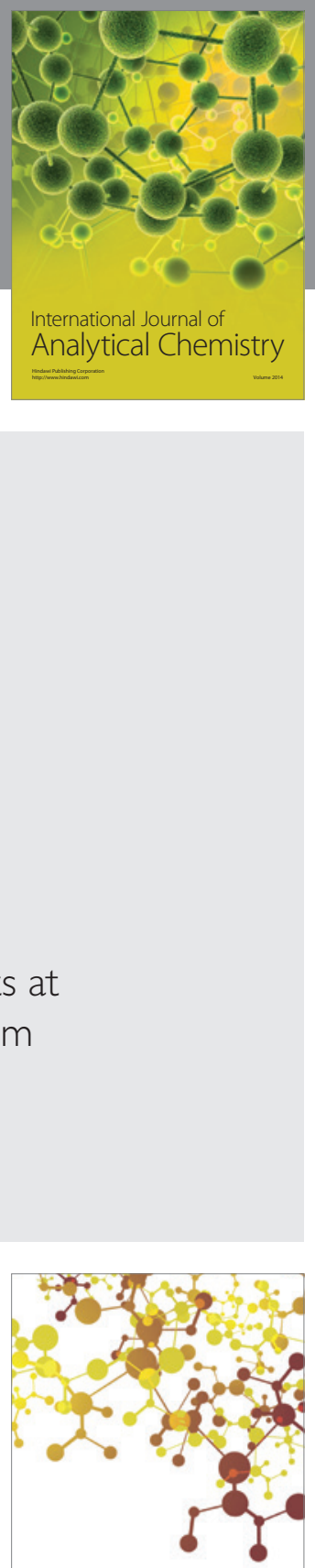

Journal of

Applied Chemistry
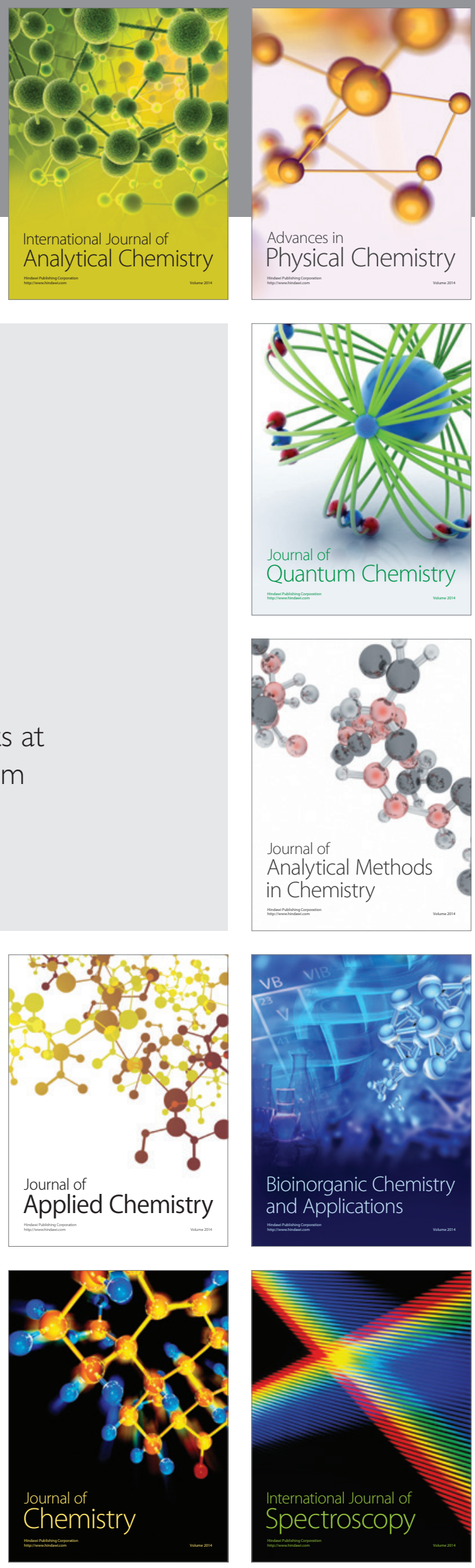